\title{
Characteristics of Gouda Cheese Supplemented with Korean Traditional Yakju
}

\author{
Heeyoung Choi ${ }^{1}$, Chulju Yang², Kapseong Choi ${ }^{3}$, Hoikyung Kim4, Delores H. Chambers ${ }^{5}$, and Inhyu Bae* \\ ${ }^{1}$ Imsil Institute of Cheese Science, Imsil-Gun 566-700, Korea \\ ${ }^{2}$ Department of Animal Science and Technology, Sunchon National University, Sunchon 540-070, Korea \\ ${ }^{3}$ Department of Food Science Science and Technology, Sunchon National University, Sunchon 540-070, Korea \\ ${ }^{4}$ Division of Human Environmental Sciences, Wonkwang University, Iksan 570-749, Korea \\ ${ }^{5}$ Department of Human Nutrition, Kansas State University, Manhattan, KS 66506, USA
}

\begin{abstract}
The quality properties of Gouda cheese supplemented with Korean traditional Yakju (Acanthopanax senticosus or Pueraria thunbergiana wines) were investigated. Yakju was added in the process of Gouda cheese preparation, and proximate composition, lactic acid bacterial population, $\mathrm{pH}$, water-soluble nitrogen, sensory characteristics and proteolysis were determined. The electrophoretic patterns of cheese proteins, the target functional components and thiobarbituric acid values of the cheeses also were analyzed. The sensory characteristics including appearance of the cheeses were not affected by supplementing Yakju. Significantly higher amounts of crude ash, minerals and polyphenols were observed in the cheese supplemented with Yakju compared to the control cheese. The results suggest that the Gouda cheese prepared with Yankju has functional and additional nutrient values without changing cheese characteristics.
\end{abstract}

Key words: Gouda cheese, yakju, quality property, medicinal wine, supplementation

\section{Introduction}

Gouda cheese is a wheel-shaped Dutch cheese that has been traditionally produced with unpasteurized raw milk (Van Slyke and Publow, 1913), and it was regularly exported to the eastern and northern European countries. Today, it is manufactured also in the EU, United States, and Japan (Herbst, 2007). In Korea, Gouda cheese was introduced to dairy farmers through cheese making education in 1997, and has been currently produced and commercialized by farmstead cheese factories and small-scale cheese makers (Bae and cho, 2006). Functional food markets have been growing worldwide including in Korea over the past decade. Since Korean traditional liquor is brewed with special herbal medicine, it is considered effective in curing various diseases such as private treatment methods. Korean traditional liquor was verified to have cell toxicity effects on DLD-1, one of colorectal

\footnotetext{
*Corresponding author: Inhyu Bae, Department of Animal Science and Technology, Sunchon National University, Suncheon 540-742, Korea. Tel: 82-61-750-3233, Fax: 82-61-750-3233, E-mail: ihbae@scnu.ac.kr
}

cancer cell lines (Kim et al., 2004). One of the most popular functional beverages consumed in Korea is medicinal-wine. Medicinal-wine has been traditionally consumed as a functional alcoholic beverage in Korea (Kim et al., 2000). Fruit beverage manufacturers have produced commercial medicinal-wines supplemented with functional ingredients, and Yakjus comprise 0.5\% (10,270 kL/year) of the alcoholic fruit beverage market in Korea. Various medicinal plants such as Acanthopanax senticosus and Pueraria thunbergiana have been used to produce Yakjus in Korea.

Acanthopanax senticosus (Gasiogapi) is a species of woody shrub in the family Araliaceae (Kim, 1997). It is a plant in the genus Acanthopanax spread in the highlands of Korea, Manchuria, Japan, China and Siberia, which has thin and long thorns on the entire stem (Nationwide Oriental Medicine College Medicinal Plants Professors). It is often colloquially referred to as Siberian ginseng. It has been reported to have antioxidant (Kim et al., 2009; Lin and Huang, 2000), anti stress (Davydov and Krikorian, 2000), anticancer (Hacker and Medom, 1984; Yoko et al., 2000), and anti allergic properties (Jeong et al., 2001; Yi et al., 2001; Yoon et al., 2002). 
Pueraria thunbergiana (Arrow root, $k u d z u$ ) is a perennial deciduous tendril plant in the pea family Fabaceae in terms of systematic botany. It is located in the temperate and tropical zones including Northeast Asia, South America and the United States (Oh, 1990). Pueraria thunbergiana survives well, so it grows naturally in the fields and mountains of all parts of Korea (Kim et al., 1996). The roots of Pueraria thunbergiana have been used as ingredients to make starch and tea and as medicine for a long time. In this way, Pueraria thunbergiana has a wide range of uses (Oh, 1990).

In this study, the effects of adding Korea traditional liquor, Yakju, to natural cheese like Gouda cheese on the physicochemical and other properties of the cheese were examined in order to develop Korean type natural cheese with western cheese quality.

\section{Materials and Methods}

\section{Yakjus}

Yakjus made of Acanthopanax senticosus (AS) or Pueraria thunbergiana (PT) were purchased at local markets in Suncheon, Korea.

\section{Preparation of Gouda cheese}

Gouda cheese was prepared as described previously (Hill, 2007; Mistry et al., 1996) with some modifications. Raw milk was obtained from the dairy farm of Suncheon National University, Suncheon, Korea. AS or PT medicinal wines, equivalent to $4.0 \%$ total in milk volume, were supplemented to fresh raw milk, and the milk containing AS or PT wines was pasteurized at $63^{\circ} \mathrm{C}$ for $30 \mathrm{~min}$ and cooled to $32^{\circ} \mathrm{C}$. The milk was held in a vat, inoculated with Probat 505 starter (Lactococcus lactis subsp. lactis, L. lactis subsp. cremoris, L. lactis subsp. lactis biovar. diacetylactis, Leuconostoc mesenteroides subsp. cremoris, Danisco, Denmark) at an inoculant concentration of $1.0 \%$ $\left(10^{10} \mathrm{CFU} / \mathrm{mL}\right)$ and incubated for $45 \mathrm{~min}$. After incubation, rennet (Naturen 290, Christian Hansen, Denmark) was supplemented at $19 \mathrm{~mL} / 100 \mathrm{~kg}$ of milk to coagulate the milk. Curds were formed, cut into $10 \mathrm{~mm}$ square pieces and agitated for $30 \mathrm{~min}$. Then the whey (30\%) was drained, and the same volume of hot water $\left(\sim 75^{\circ} \mathrm{C}\right)$ was supplemented to the curds to dilute the lactose concentration in the whey and to keep a final temperature of $38^{\circ} \mathrm{C}$. After $1.0 \mathrm{~h}$ of agitation, half of the remaining whey was removed and the curd was pressed with the same weight of the curd for $1.0 \mathrm{~h}$. When the $\mathrm{pH}$ of the cheese reached 5.3 , it was pressed with twice the curd weight for $2.0 \mathrm{~h}$, immersed in $20 \%$ brine for $8 \mathrm{~h} / \mathrm{kg}$ and ripened at $14^{\circ} \mathrm{C}$ with a $90-95 \%$ relative humidity for $15 \mathrm{wk}$.

\section{Enumeration of lactic acid bacteria (LAB)}

The numbers of LAB were monitored every 3 weeks during ripening. Samples were mixed with sterilized saline at a ratio of 1:2 and homogenized (M. Zipper $\mathrm{GmbH}$, Germany) at maximum speed for $2 \mathrm{~min}$. According to the method of Andrew (1983), $1.0 \mathrm{~mL}$ of homogenized sample was aseptically diluted with sterilized saline and spread on MRS agar (BBL/Difco, USA). The MRS agar plates were incubated at $37^{\circ} \mathrm{C}$ for $48 \mathrm{~h}$ and the colonies were counted.

\section{pH measurement}

The cheese samples were homogenized with sterile saline at the ratio of one to two and measured using the pH meter (IQ Scientific Instruments Inc, USA).

\section{Water soluble nitrogen (WSN)}

In order to measure the total protein decomposition level while ripening the cheese, change in WSN (water soluble nitrogen) was measured according to the method of Bütikofer (1993), and Hull et al. (2006).

That is, the sample for measuring its change was homogenized and centrifuged (Supra 25K, Hanil Science Industrial, Korea)as shown in the $\mathrm{pH}$ measurement and then the filtrate (Whatman No.2) was colored according to the method of Hull (1947). Next the content of WSN was measured in $570 \mathrm{~nm}$ by using the UV- Spectrophotometer (Smart Plus Spectrophotometer Co., Korea). The content of a nitrogenous compound was calculated according to the linear regression equation obtained by making tyrosine as a standard substance.

\section{Gel electrophoresis of casein}

Polyacrylamide gel electrophoresis of a casein sample was performed according to the method of Laemmli (1970) and Creamer (1982). The cheese sample was prepared by an addition of $6 \mathrm{ml}$ of TCA (12.0\%) to the cheese $(0.3 \mathrm{~g})$, sedimentation, and filtration with a filter paper (Whatman No. 42). The filtrates were dissolved with $0.076 \mathrm{M}$ Tris-citrate buffer (pH 9.0) at ca. $30 \mathrm{mg} /$ $\mathrm{mL} .40 \mu \mathrm{L}$ of solution dialyzed with electrode buffer for $48 \mathrm{~h}$ were boiled in the SDS sample buffer $(\times 5)$ for $3 \mathrm{~min}$ to denature the proteins. The boiled samples were carefully loaded up to $10 \mu \mathrm{L}$ and the current level was adjusted to $30 \mathrm{~mA}$ for a $1.5-\mathrm{mm}$-thick gel and electrophoresis started. The gel was prepared at a $\mathrm{pH}$ of 8.8 and 
15\%. Whole casein (Bio-Rad Laboratories, Hercules, CA, USA) was used as a standard protein marker. After the electrophoresis had been completed, the gel was stained with Coomassie brilliant blue Gel Stain, then bleached, and photographed.

\section{Determination of polyphenol content}

To determine the polyphenol content in the cheeses, extracts $(100 \mathrm{~mL})$ were obtained by adding ethanol to the homogenized samples. Extracts ( $5 \mathrm{~mL}$ ) obtained after discarding the first $20 \mathrm{~mL}$ were discarded and mixed with 5 $\mathrm{mL}$ of ferrous tartrate stock solution $\left(100 \mathrm{mg} \mathrm{FeSO}_{4}\right.$ $7 \mathrm{H}_{2} \mathrm{O}+500 \mathrm{mg} / 100 \mathrm{~mL} \mathrm{H}_{2} \mathrm{O}$ Rochelle salt), and the $\mathrm{pH}$ was adjusted to 7.5 with $0.066 \mathrm{M} \mathrm{Na}_{2} \mathrm{HPO}_{4} 2 \mathrm{H}_{2} \mathrm{O}+$ $0.066 \mathrm{M} \mathrm{KH}_{2} \mathrm{PO}_{4}$. The absorbency of the treated extracts was then measured at a wavelength of $540 \mathrm{~nm}$ using a spectrophotometer.

\section{Proximate composition analysis}

AOAC methods (1990) were used to determine the moisture, protein, and fat content in the cheeses.

\section{Analysis of thiobarbituric acid (TBA) value}

Cheeses that had completely ripened were stored in a refrigerator for $0-5 \mathrm{wk}$ and the rancidity was measured. Cheese samples $(20 \mathrm{~g})$ were supplemented to $50 \mathrm{~mL}$ of $2.0 \mathrm{M}$ phosphoric acid with $20 \%$ TCA to obtain extracts. Residues of the extracts were diluted in $40 \mathrm{~mL}$ of distilled water, homogenized, and filtered with Whatman no. 1 paper. Then, the filtrates $(5 \mathrm{~mL})$ were mixed with 2 thiobarbituric acid and maintained for $15 \mathrm{~h}$ at room temperature. Next, the absorbency was read at $530 \mathrm{~nm}$ using a visible spectrum spectrophotometer (Model 20D', Milton Roy, Ivyland, USA).

\section{Sensory evaluation}

The cheeses were tested in triplicate by a highly trained panel of seven assessors at Kansas State University ${ }^{\circ}$ Øs Sensory Analysis Center, KS, USA. A 0-15 scale was used and the answers to 27 questions were evaluated (Otremba et al., 2000; Shin et al., 2000).

\section{Statistical analysis}

The data was analyzed using the ANOVA procedure in Statistical Analysis Systems software (SAS Institute, Cary, NC, USA). Fisher's least significant difference test was used to determine differences in chemical compositions and polyphenol content between cheeses supplemented with medicinal wines and those without supple- mented wine. The significance was detected at the $95 \%$ confidence level $(p \leq 0.05)$.

\section{Results and Discussion}

\section{Appearance}

Fig. 1 show the appearance of the Gouda cheeses made with Korean traditional Yakju matured for 15 wk. There were no significant differences in the appearance of the cheeses between the Control and sample cheeses; however, the cheese supplemented with wines tended to become slightly dark yellow in color. It was considered that dark colored Gouda cheese can be favored by market consumers.

\section{Composition}

The chemical composition and mineral composition of the Gouda cheese supplemented with Yakjus is shown in Table 1 and Table 2. The moisture contents were similar among the cheeses; the control cheese was at a range to $36.2 \%$, AS or PT wines had the contents of 35.4 and

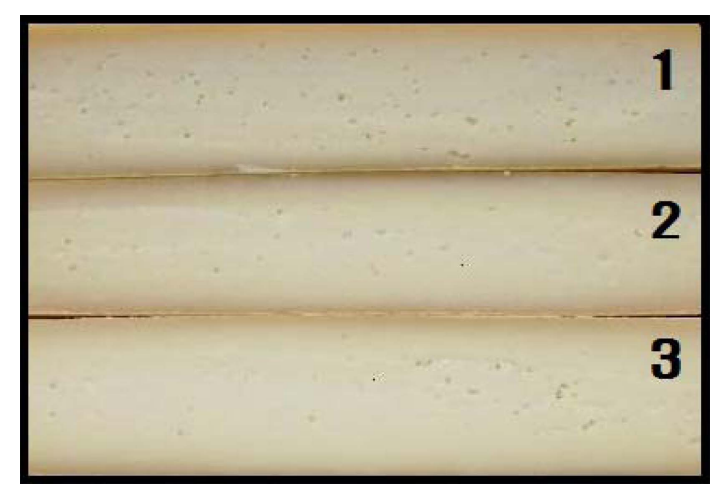

Fig. 1. Appearance of Gouda cheese supplemented with traditional Korean Yakju. 1, Control Gouda cheese; 2, Acanthopanax senticosus (AS) wine supplemented cheese; 3, Pueraria thunbergiana (PT) wine supplemented cheese.

Table 1. Chemical composition of the Gouda cheese supplemented with traditional Korea Yakju

\begin{tabular}{lrrr}
\hline \hline \multirow{2}{*}{$\begin{array}{c}\text { Component } \\
(\%)\end{array}$} & \multicolumn{3}{c}{ Wine-supplemented cheeses ${ }^{1)}$} \\
\cline { 2 - 4 } & \multicolumn{1}{c}{ Control } & \multicolumn{1}{c}{ AS wine } & \multicolumn{1}{c}{ PT wine } \\
\hline Moisture & $36.2 \pm 0.40$ & $35.4 \pm 0.20$ & $36.3 \pm 0.36$ \\
Crude ash & $3.3 \pm 0.11$ & $4.7 \pm 0.05$ & $4.0 \pm 0.15$ \\
Crude protein & $27.2 \pm 0.20$ & $29.8 \pm 0.35$ & $29.5 \pm 0.05$ \\
Crude fat & $33.3 \pm 0.30$ & $30.7 \pm 0.15$ & $30.2 \pm 0.15$ \\
\hline
\end{tabular}

Mean \pm SD $(n=15)$.

Means in each column with different superscripts differ significantly $(p<0.05)$

${ }^{1)}$ Contral, Gouda cheesse; Aswine, Acanthopanax senticosus (AS) wine supplemented chees; PT win, Pueraria thunbergiana (PT) wine supplemented cheese 
$36.3 \%$. The control cheese had a crude protein content of $27.2 \%$, while the cheese made with AS or PT wines had the contents of 29.8 and $29.5 \%$. The crude fat content of the control cheese was $33.3 \%$, and that with Yakju ranged from $30.7-30.2 \%$. The crude ash content was lower in the control cheese compared with those containing Yakju. Cheese supplemented with AS wine had the highest crude ash $(4.7 \%)$ among the cheese samples. The mineral content $(\mathrm{Fe}, \mathrm{mg}$ ) was significantly higher in checse containing AS wine and PT wine compared with those of Yakju. This result was partly caused by the high amount of crude ash and minerals $(5951 \mathrm{mg}$ of $\mathrm{K} / 100 \mathrm{~g}$ and $286 \mathrm{mg}$ of $\mathrm{Mg} / 100 \mathrm{~g}$ ) in AS wine (Kim et al., 2006).

\section{Lactic acid bacteria (LAB)}

Populations of LAB were significantly higher in the cheeses supplemented with Yakjus than in the Control (Fig. 2). Cheese supplemented with PT wine had slightly higher numbers of LAB than those made with AS wine in the beginning of ripening. The $\mathrm{LAB}$ population in the cheese with AS wine was low at the initial ripening time, but after $6 \mathrm{wk}$, it was higher than those of the Control cheese, which was due to the biologically active substances that originated from the wine.

\section{pHs}

The $\mathrm{pH}$ values (5.10-5.29) of the cheese supplemented with wines were slightly lower than that of the Control cheese. Cheeses with and without wines changed to normal $\mathrm{pH}$ of standard Gouda cheese ( $\mathrm{pH}$ 5.20). The increase of the $\mathrm{pH}$ during ripening may be caused by decarboxylation and deamination of amino acids in the cheeses (Bachmann et al., 1999).

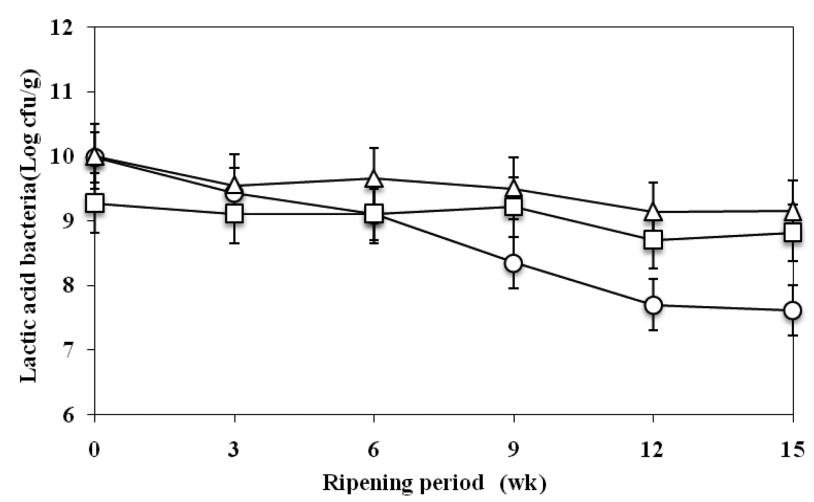

Fig. 2. Changes in LAB count of wine supplemented Gouda cheese during ripening. $\bigcirc-\bigcirc$, Control Gouda cheese; $\square$ $\square$, AS wine supplemented cheese; $\triangle$ - $\triangle$, PT wine supplemented cheese

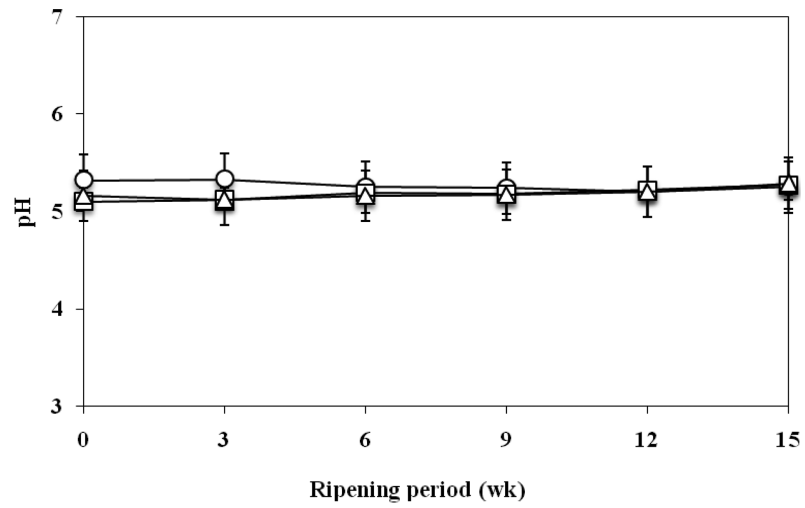

Fig. 3. Changes in pH of wine supplemented Gouda cheese during ripening. $\bigcirc-\bigcirc$, Control Gouda cheese; $\square-\square$, AS wine supplemented cheese; $\triangle-\triangle$, PT wine supplemented cheese

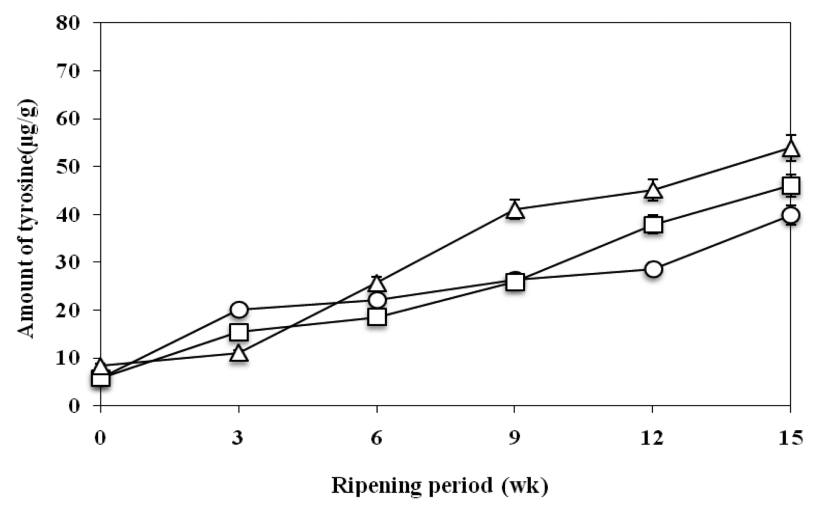

Fig. 4. Changes in water-soluble nitrogen (WSN) content of wine supplemented Gouda cheese during ripening. $\bigcirc$ $\bigcirc$, Control Gouda cheese; $\square$ - $\square$, AS wine supplemented cheese; $\triangle-\triangle$, PT wine supplemented cheese

\section{Water-soluble nitrogen (WSN)}

The content of WSN in the cheeses was changed rapidly during the ripening period (Fig. 4), resulting from proteolysis. Higher amounts of WSN were observed in the Control cheese until $3 \mathrm{wk}$, but the amount became lower after 9 wk compared to the cheeses supplemented with wines. The WSN content in cheeses with Yakjus increased continuously for $12 \mathrm{wk}$, whereas the WSN content in the Control cheese did not. The increase of WSN in the cheese generally comes from casein degradation, and it usually depends on the proteases produced by the lactic starters and the nitrogen associated with the rennet used in cheese manufacturing (Galan et al., 2008). It was also noted that protease produced by LAB in cheeses causes constant protein degradation (Sallami et al., 2004). Apparently, the compounds in Yakjus also promoted continual degradation and increased WSN throughout. 

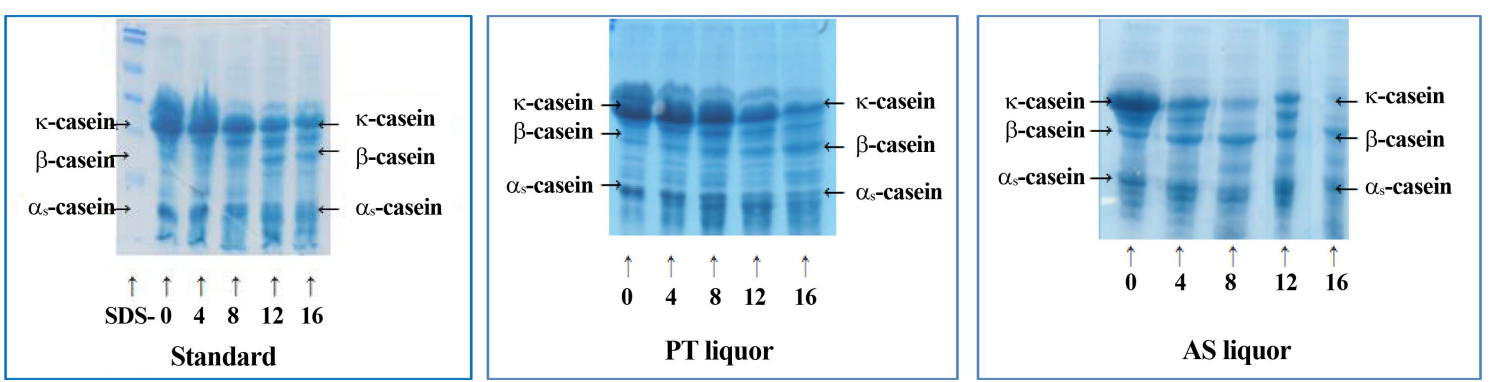

Fig. 5. Proteolytic activity of Gouda cheese supplemented with traditional Korean Yakju during ripening PT wine.

\section{Casein proteolysis}

Fig. 5 shows the electrophoretic patterns of the cheese proteins during ripening. The samples were obtained at 4wk intervals for $16 \mathrm{wk}$ and analyzed by SDS-PAGE as described previously (Andrews, 1983). Several bands that were displayed on the gel indicate that the cheeses with wines were ripened with significant degradation compared to the Control cheese. This result was similar to the report by Fox et al. (Fox and Stepaniak, 1993). It is well established that $\alpha_{\mathrm{s}}$-casein, $\beta$-casein and $\mathrm{k}$-casein were gradually hydrolyzed as the cheese ripened and the $\alpha_{\mathrm{s}}$ casein proteolysis occurrence was almost similar. In this study, $\alpha_{\mathrm{s}}$-casein was not detected after 8 weeks of ripening, implying proper degradation patterns in the cheese samples.

\section{Determination of polyphenols, anthocyanin and flavonoids content}

Table 3 shows the amounts of polyphenols, anthocyanin and flavonoids in the Yakjus used in this study. AS wine had higher amounts of polyphenols $(2.1 \mathrm{mg} \%)$ and

Table 2. Mineral composition of Gouda cheese supplemented with Korea traditional Yakju

\begin{tabular}{crrr}
\hline \hline \multirow{2}{*}{$\begin{array}{c}\text { Mineral } \\
\text { Component }\end{array}$} & \multicolumn{3}{c}{ Wine-supplemented cheeses } \\
\cline { 2 - 4 } & \multicolumn{1}{c}{ Control } & \multicolumn{1}{c}{ AS wine } & \multicolumn{1}{c}{ PT wine } \\
\hline $\mathrm{Fe}$ & $1.4 \pm 0.05$ & $4.0 \pm 0.15$ & $3.2 \pm 0.20$ \\
$\mathrm{Mg}$ & $7.0 \pm 0.15$ & $37.6 \pm 0.15$ & $19.7 \pm 0.05$ \\
$\mathrm{Ca}$ & $542.5 \pm 0.35$ & $346.6 \pm 1.24$ & $272.3 \pm 5.30$ \\
\hline
\end{tabular}

Mean \pm SD $(n=15)$, Means in each column with different superscripts differ significantly $(p<0.05)$.

Table 3. Polyphenol, anthocyanin and flavonoid contents in Korea traditional Yakju

\begin{tabular}{cccc}
\hline \hline & Polyphenol & Anthocyanin & Flavonoids \\
\hline AS wine & $2.1 \pm 0.05$ & $0.3 \pm 0.35$ & $36.3 \pm 0.20$ \\
PT wine & $1.9 \pm 0.11$ & $0.3 \pm 0.26$ & $21.3 \pm 0.28$ \\
\hline
\end{tabular}

Mean \pm SD $(n=15)$, Means in each column with different superscripts differ significantly $(p<0.05)$. flavonoids (36.3 $\mathrm{mg} \%$ ) than PT wine, but the amount of anthocyanin $(0.3 \mathrm{mg} \%)$ was similar. The polyphenol content in the cheeses made with or without Yakjus is listed in Table 3. The contents of polyphenols in cheese made with wines were comparatively high; 19.91-20.05 mg/100 $\mathrm{g}$ for the cheese during the initial 9 wk. Its contents remained at these levels until the end of ripening.

\section{Analysis of thiobarbituric acid}

The TBA values of the cheeses supplemented with AS or PT wines were periodically measured for 9 mon after ripening (Fig. 6). The TBA levels of all cheeses were similar during the initial storage time of $2 \mathrm{mon}$. The TBA value of cheese supplemented with PT wines decreased slightly thereafter, and it was not changed until 9 mon, whereas the value of the cheese supplemented with AS wine increased rapidly after $7 \mathrm{mon}$. The TBA values of the cheeses with AS or PT wine ranged between 5 and 20 $\mathrm{mmol} / 100 \mathrm{~g}$, after 9 mon of storage. However, the value of the Control cheese increased dramatically after 3 to 6 mon but decreased gradually thereafter. After 9 mon of storage, the TBA value reached $40 \mathrm{mmol} / 100 \mathrm{~g}$. These results showed that antioxidant materials i.e. polyphenols,

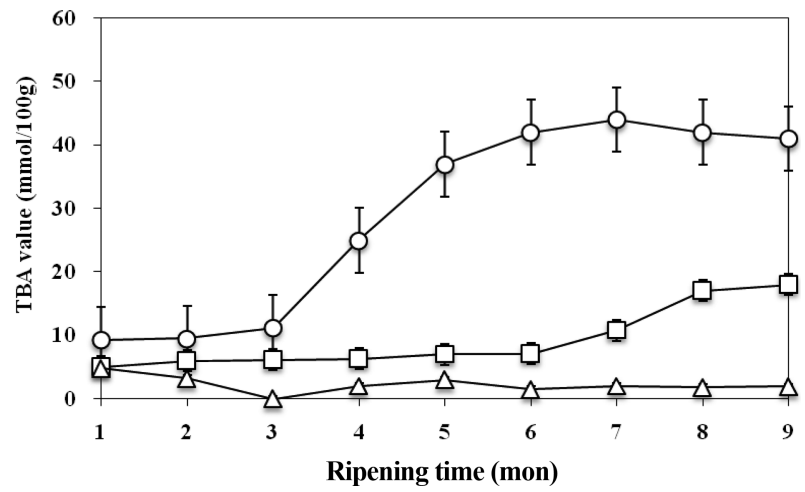

Fig. 6. Changes in Thiobarbituric acid (TBA) values of wine supplemented Gouda cheese during ripening. $\bigcirc-\bigcirc$, Control Gouda cheese; $\square-\square$, AS wine supplemented cheese; $\triangle-\triangle$, PT wine supplemented cheese 


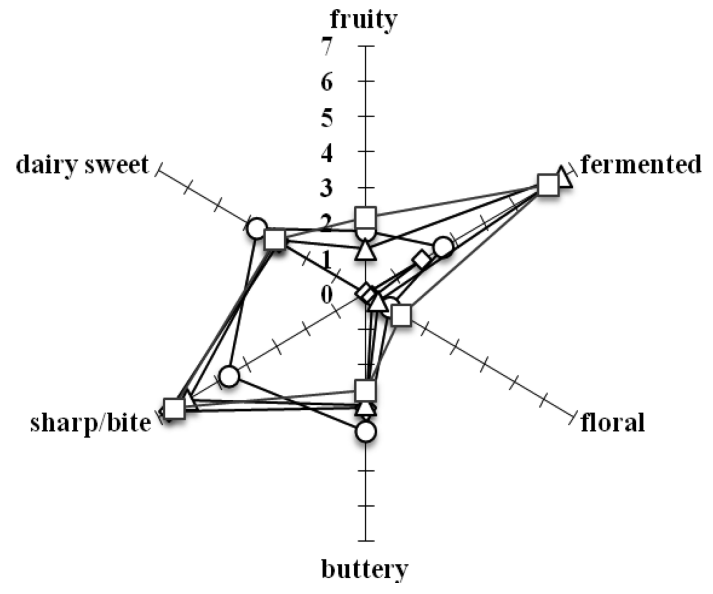

Fig. 7. Sensory evaluation of Gouda cheese supplemented

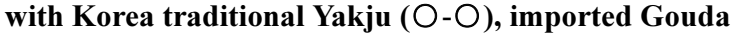
cheese $(\diamond-\diamond)$, with AS wine $(\square-\square)$ and PT wine $(\Delta-\Delta)$.

retarded the oxidation process for the cheeses with Yakju. It is suggested that adding Yakjus to cheeses can directly impact the shelf life of the cheese products.

\section{Sensory evaluation}

The sensory attributes of the test Gouda cheeses made were compared with imported Gouda cheese after $14 \mathrm{wk}$ of the ripening period (Fig. 7). Cheese flavor, such as the Thage et al. (2004) reports that leucine, and the valine amino acids were important functional flavors. A fermented taste and a sharpness/bitterness were predominant in the cheeses supplemented with AS or PT wine. However, typical flavors of dairy sweetness and fruity, buttery, floral tastes were not affected by the addition of Yakju.

The results of this study indicate that adding AS or PT wine to Gouda cheese provides several benefits; adding the wines increased the lactic acid bacterial populations in the cheese by forming biologically active substances. The higher populations of LAB in the cheeses produced more proteases, resulting in a higher level of WSN. Furthermore, the polyphenols in Yakjus possibly retard cheese oxidation and prolong the shelf-life of the products. Therefore, it is concluded that the quality of Gouda cheese was not affected by adding Korean traditional wines. Also various components in the wines had functionalities for the cheese products.

\section{Acknowledgment}

This research was supported by Technology Development Program for ('Agriculture and Forestry' or 'Food' or 'Fisheries'), Ministry for Food, Agriculture, Forestry and Fisheries, Republic of Korea.

\section{References}

1. Andrews, A. T. (1983) Proteinases in normal bovine milk and their action on caseins. J. Dairy Res. 50, 45-55.

2. AOAC (1990) Official methods of analysis. 13th ed, Association of Official Analytical Chemists, Washington, DC, pp. 125-139.

3. Bachmann, H. P., Bütikofer, U., and Meyer, J. (1999) Predication of flavor and texture development in Swiss-type cheese. Lebensm. Wiss. Technol. 32, 284-289.

4. Bae, I. and Cho, S. K. (2006) Status and prospect of education, training, production and company establishment of farmstead cheese-making in Korea. Kor. J. Dairy Sci. Technol. 24, 11-20.

5. Davydov, M. and Krikorian, A. D. (2000) Eleutherococcus senticosus maxim. (Araliaceae) as an adaptogen: a closer look. J. Ethnopharmacol. 72, 345-393.

6. Fox, P. F. and Stepaniak, L. (1993) Enzymes in cheese technology. Int. Dairy J. 3, 509-530.

7. Galan, E. P. F., Pino, A., Tejada, L., and Fernandez-Salguero, J. (2008) Influence of different amounts of vegetable coagulant from cardoon Cynara cardunculus and calf rennet on the proteolysis and sensory characteristics of cheeses made with sheep milk. Int. Dairy J. 18, 93-98.

8. Hacker, B. and Medom, P. (1984) Cytotoxic effects of E. senticosus aqueous extract against L1210 leukemia cells. $J$. Pharm. Sci. 73, 270-272.

9. Herbst, S. T. and Herbst, R. (2007) The cheese lover's companion. Harper Collins Pub. Co., NY, pp. 225-228.

10. Hill, A. R. (2007) Cheese science and cheese-making technology (Korean version translated by Bae, I. and Ahn, J. K.). Yuhan Munhwa Publ. Co., Seoul, Korea. pp.58-66.

11. Jeong, H. J., Koo, H. N., Myung, N. I., Shin, M. K., Kim, J. W., Kim, D. K., Kim, K. S., Kim, H. M., and Lee, Y. M. (2001) Inhibitory effects of mast cell-mediated allergic reactions by cell cultured Siberian ginseng. Immunopharmacol. Immunotoxicol. 23, 107-117.

12. Kim, C. H. (1997) Systematics of Eleutherococcus and related genera (Araliceae). Ph.D. thesis, Chonbuk National University, Jeonju, Korea.

13. Kim, I. C. and Hur, S. S. (2009) Antioxidative properties and whitening effects of the Aatragali radix, Atractylodis rhizoma Alba and Acanthopanacisc cortex. J. Korean Oil Chem. Soc. 26, 110-116.

14. Kim, I. H., Park, W. S., and Koo, Y. J. (1996) Comparison of fermentation characteristics of Korean traditional alcoholic beverage with different input step and treatment of rice and Nuruk (Korean-Style Bran Koji). Kor. J. Food Culture 11, 339-348.

15. Kim, J. H., Lee, D. H., Choi, S. Y., Yoo, J. Y., and Lee, J. S. (2000) Manufacture and physiological functionality of Korea traditional liquors by using Dandelion. Kor. J. Appl. Microbiol. Biotech. 28, 367-371.

16. Kim, M. K., Jin, Y. S., Heo, S. I., Tae, H. S., Sa, J. H., and Wang, M. H. (2006) Studies for component analysis and antioxidant effect, antimicrobial activity in Acanthopanax 
senticosus HARMS. Kor. J. Pharmacogn. 37, 151-156.

17. LaemmLi, U. K. (1970) Cleavage of structural proteins during the assembly of the head of bacteriophage T4, Nature 227, 680-685.

18. Lin, C. C. and Huang, P. C. (2000) Antioxidant and hepatoprotective effects of Acanthopanax senticosus. Phytother. Res. 14, 489-494.

19. Mistry, V. V. and Pulgar, J. B. (1996) Use of high milk protein powder in the manufacture of Gouda cheese. Int. Dairy J. 6, 205-216.

20. Oh, M. J. (1990) Antioxidative components of Pueraria root. Kor. J. Food Sci. 22, 793-798.

21. Otremba, M. M., Dikeman, M. E., Milliken, G. A., Stroda, S. L., Chambers, IV. E., and Chambers, D. (2000) Interrelationships between descriptive texture profile sensory panel and descriptive attribute sensory panel evaluations of beef Longissimus and Semitendinosus muscles. Meat Sci. 54, 325-332.

22. Richardson, G. H., Ersstron, C. A., Kim, M. J., and Daly, C. (1983) Proteinase negative variants of Streptococcus cremoris for cheese starters. J. Dairy Sci. 66, 2278-2286.

23. Sallami, L., Kheadr, E. E., Fliss, I., and Vuillemard, J. C. (2004) Impact of autolytic, proteolytic, and nisin-producing adjunct cultures on biochemical and textural properties of
Cheddar cheese. J. Dairy Sci. 87, 1585-1594.

24. Shin, Y. J., Kim, K. S., and Park, G. S. (2009) Texture and sensory characteristics of fish paste containing white Poria cocos wolf powder. Kor. J. Food Cookery Sci. 25, 119-125.

25. Yi, J. M., Kim, M. S., Seo, S. W., Lee, K. N., Yook, C. S., and Kim, H. M (2001) Acanthopanax senticosus root inhibits mast cell-dependent anaphylaxis. Clin. Chem. Acta. 312, 163-168.

26. Yoko, T., Takashi, I., and Hiroyuki, F. (2000) Dietary gamma-linolenic acid in the form of borage oil causes less body fat accumulation accompanying an increase in uncoupling protein $1 \mathrm{mRNA}$ level in brown adipose tissue. Comp. Biochem. Physiol. B: Biochem. Mol. Biol. 127, 213-222.

27. Yoon, T. J., Lee, S. W., Shin, K. S., Choi, W. H., Hwang, S. H., Seo, S. H., Kim, S. H., and Park, W. M. (2002) Effect of hot water extract from Acanthopanax senticosus on systemic anaphylaxis. Kor. J. Food Sci. Technol. 34, 518-523.

28. Van Slyke, L. L. and Publow, C. A. (1913) The science and practice of cheese-making. Orange Judd Co., NY, pp. 415419.

(Received 2011.8.8/Revised 2011.11.3/Accepted 2011.11.30) 